\title{
Groundwater Quality Determination for Drinking Purpose by Using Water Quality Index Technique: A Case Study of Gadap Town, Karachi, Pakistan
}

\author{
Asal Eghbal Bakhtiari ${ }^{1}$ \\ Adnan Khan ${ }^{\rtimes}$ (iD) \\ Zubaid Saeed $^{3}$ iD \\ Ayesha Kanwal $^{4}$ (D)
}

${ }^{1,2,3,4}$ Department of Geology, University of Karachi, Karachi, Pakistan.

Email:asalbakhtyari@gmail.com Tel:+92-331-2444760

Email:adkhan@uok.edu.pkTel:+92-s00-3635848

${ }^{3}$ Email:zubaid.saed@gmail.com Tel: +92-333-3801218

¿Email:akanwal893@gmail.com Tel: +92-332-2421452

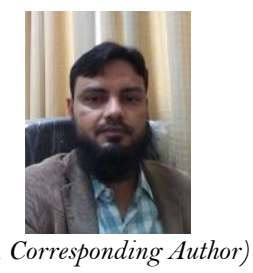

\section{Abstract}

Present study is aimed at assessment of groundwater quality of Gadap Town for drinking purpose using water quality index (WQI) technique. Gadap is located in the outskirt of Karachi city and mainly influenced by the agriculture activities. Groundwater samples $(\mathrm{n}=22)$ were collected mainly from boring wells and a few through tube wells from variable depths (100-600 feet). The analytical results of water reveal occurrence of very high TDS (range: 466-3810; mean: 1402) and hardness contents (range: $250-2800 \mathrm{mg} / \mathrm{L}$ ). On the other hand, $\mathrm{pH}$ varies (range: 6.9-8.1; mean: $7.5)$ within WHO guidelines (6.5-8.5) with a few samples showing turbidity. About one third of total collected samples $(\mathrm{n}=8)$ were analyzed for qualitative determination of microbial contamination which are found positive, except one sample, indicating the sewage mixing. Major chemistry of groundwater is also found disturbed in terms of high content of $\mathrm{Na}$ (mean: 219 $\mathrm{mg} / \mathrm{L}$ ), $\mathrm{K}$ (mean: $15 \mathrm{mg} / \mathrm{L}$ ), Ca (mean: 144 mg/L) and $\mathrm{Mg}$ (mean: mg/L 137). Similarly, anions varied in the order of $\mathrm{Cl}>\mathrm{HCO} 3>\mathrm{SO} 4>\mathrm{NO} 3$. Although some parameters show the bad quality of water but Water quality index (WQI) value (16.18) indicates that the groundwater quality is suitable for drinking purpose. It is inferred from the present study that water quality is partly polluted due to anthropogenic activities mainly by sewage infiltration.

Keywords: Groundwater, Geochemistry, Drinking quality, WQI, Gadap Town, Karachi.

Citation | Asal Eghbal Bakhtiari; Adnan Khan; Zubaid Saeed; Ayesha Kanwal (2019). Groundwater Quality Determination for Drinking Purpose by Using Water Quality Index Technique: A Case Study of Gadap Town, Karachi, Pakistan. Asian Review of Environmental and Earth Sciences, 6(1): 70-77.

History:

Received: 3 September 2019

Revised: 7 October 2019

Accepted: 13 November 2019

Published: 30 December 2019

Licensed: This work is licensed under a Creative Common Attribution 3.0 License $(\mathrm{cc}) \mathbf{E}$

Publisher: Asian Online Journal Publishing Group
Acknowledgement: Authors are indebted to Department of Geology, University of Karachi for providing the analytical facilities. Dr. Ghulam Murtaza Arain, laboratory Incharge of Pakistan Council for Research in Water Resources (PCRWR) is also thanked for analyzing the samples to determine some parameters.

Funding: This study received no specific financial support.

Competing Interests: The authors declare that they have no conflict of interests.

Transparency: The authors confirm that the manuscript is an honest, accurate, and transparent account of the study was reported; that no vital features of the study have been omitted; and that any discrepancies from the study as planned have been explained.

Ethical: This study follows all ethical practices during writing.

\section{Contents}

1. Introduction

2. Materials and Methods

(a) 71

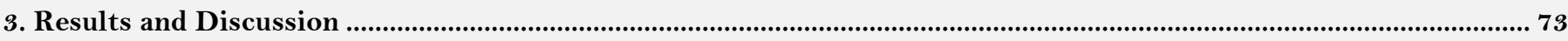

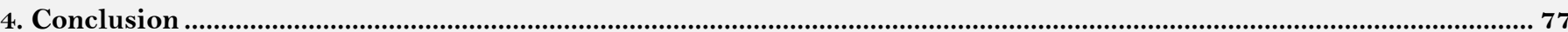

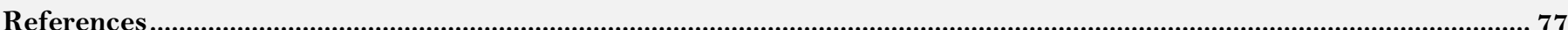




\section{Contribution of this paper to the literature}

This paper will augment the worth of WQI technique being used for explaining the water quality objectively. It will also add the information about groundwater behavior occurring in the suburbs of the mega city.

\section{Introduction}

Groundwater is one of the imperative natural resource to drive the life cycle. It is widely used for various purposes including industry, drinking, washing and irrigation. It can only be used if available in sufficient quantity with acceptable quality [1]. Hydrological cycle naturally works as a big pump which continuously transfers the water from oceans to land; mainly underground [2]. Modern agricultural practices, urbanization and industrialization have created the menace of water pollution [3]. These anthropogenic activities not only alter the physicochemical characters of water bodies but also contaminate the environment. Once the groundwater gets polluted it is difficult and costly to be cleaned up. Hence, to identify the potential toxicants and mechanism of release from their sources is important to prevent these water resources. Agricultural practices are common in areas where the fertile soil and water is available in copious amount. However, due to nutrient deficiency in agricultural soils, plenty of fertilizer or manure is used to get required crop yield. On the other hand, eutrophication, a result of high nutrient loads (mainly nitrogen and phosphorus), is considered to be the prevailing water quality problem for surface water [4]. Other pollutants originating in agricultural activities include sediments, oxygen-demanding substances and pesticides. Similarly, salinization is also reported as the most widespread groundwater quality problem and as having the greatest environmental and economic impacts [5]. This in turn leads to release various toxic elements into the water which ultimately contaminate the groundwater resources. This groundwater is also used by the dwellers of the agriculture-based community as main source of cooking, washing and drinking. As a result, the health and life of such community gets threatened. It is therefore important to monitor and regulate the groundwater of such areas to prevent from any catastrophe.

About $60 \%$ of urban population in Pakistan is using groundwater for drinking and domestic purpose without regulating the water as per World Health Organization (WHO) standards [1]. Karachi is the largest city of Pakistan which is blessed with several ephemeral streams and channels culminating at two main rivers namely Lyari and Malir which ultimately discharge to Arabian Sea. The land around these natural water courses is being used for agricultural activities since long. Some agricultural sites are still pristine however others are rapidly transforming into the urban centers. Gadap Town is the agricultural periphery of Karachi city which is the hub of vegetable supply to this mega city and adjoining areas. Some reports on the base line data have shown the occurrence of high nitrate in the groundwater of Gadap (e.g. Chughtai, et al. [6]). As a result, the health of people living in Gadap town is questioned. However, no detailed work has been carried out so far to address the groundwater quality and possible sources of contamination in this part of Karachi city. Therefore, present study is aimed at assessing the groundwater quality of Gadap town using a new approach i.e. water quality index (WQI). Other objective is to statistically trace out the factors responsible for influencing the chemistry of groundwater in study area.

\section{Materials and Methods}

\subsection{Study Area}

Gadap town is subdivision of Malir district which situated in the northwestern part of Karachi city Figure 1. This town is also forming the provincial border between Sindh and Balochistan, while to the north and east are Jamshoro district and the Kirthar Mountains. Gadap town has 8 union councils with over 400 rural villages accommodating the population of about 289,564 (1998). Gadap basin is influenced by the ephemeral channels occurring in the outskirt of Karachi city and mainly influenced by the agriculture activities. Over the last decade the Gadap is transformed into semi-area urban.

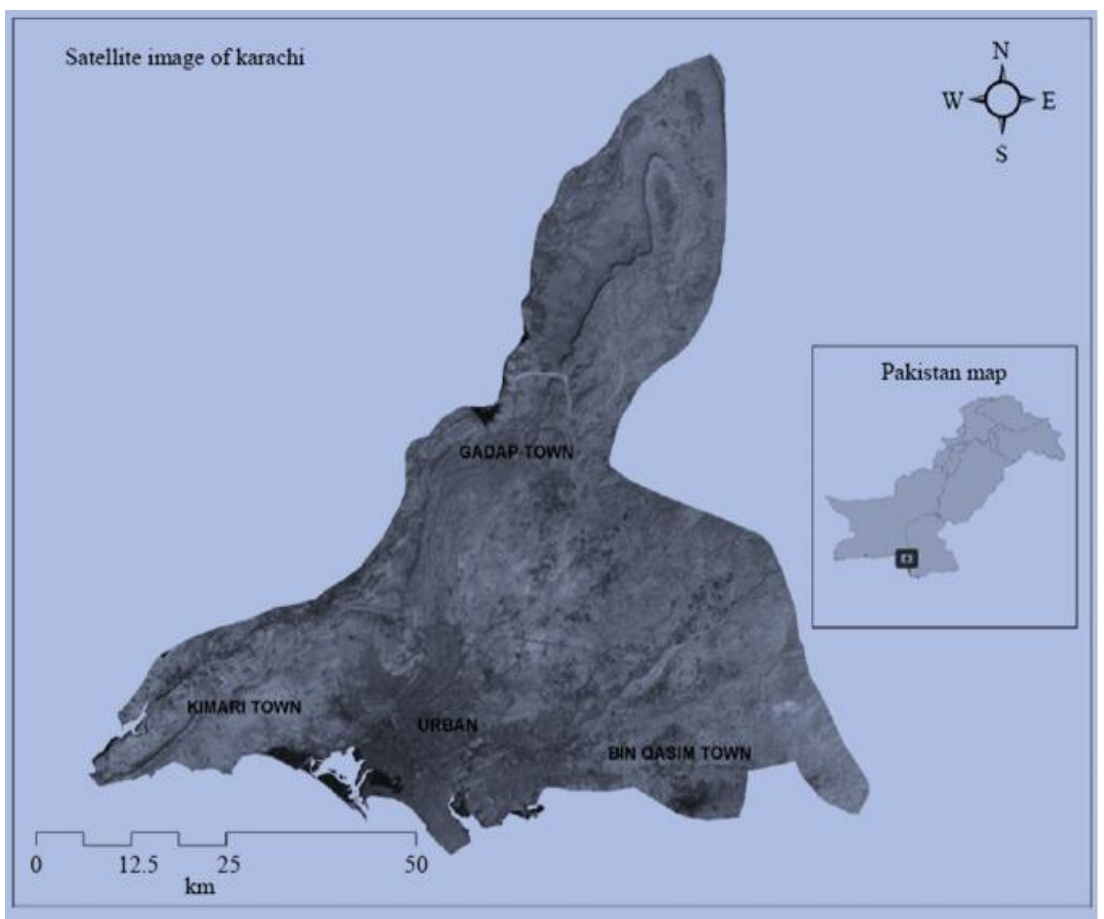

Figure-1. Location map of Gadap Town, Karachi, (after Mahboob, et al. [7])

Source: This map has been taken from Mahboob, et al. [7] paper which is cited in the figure caption. 


\subsection{Sample Collection}

Twenty-two groundwater samples were collected from boring wells at a depth range of 100-600ft. Groundwater was electrically pumped for 2-3 minutes to get true samples. Location of the wells was marked with the help of Global Positioning System (GPS) on the Google earth image and transformed on the map prepared by using GIS Technique Figure 2. Groundwater samples were collected in plastic bottles of 1.5-liter capacity for physico-chemical analysis. Bottles were properly washed and rinsed thoroughly with distilled water and then with groundwater at sampling site. To determine nitrate concentration groundwater samples were collected in bottles of $100 \mathrm{ml}$ capacity and one $\mathrm{ml}$ boric acid solution was injected through sterile syringe in each water sample to cease any further reaction.

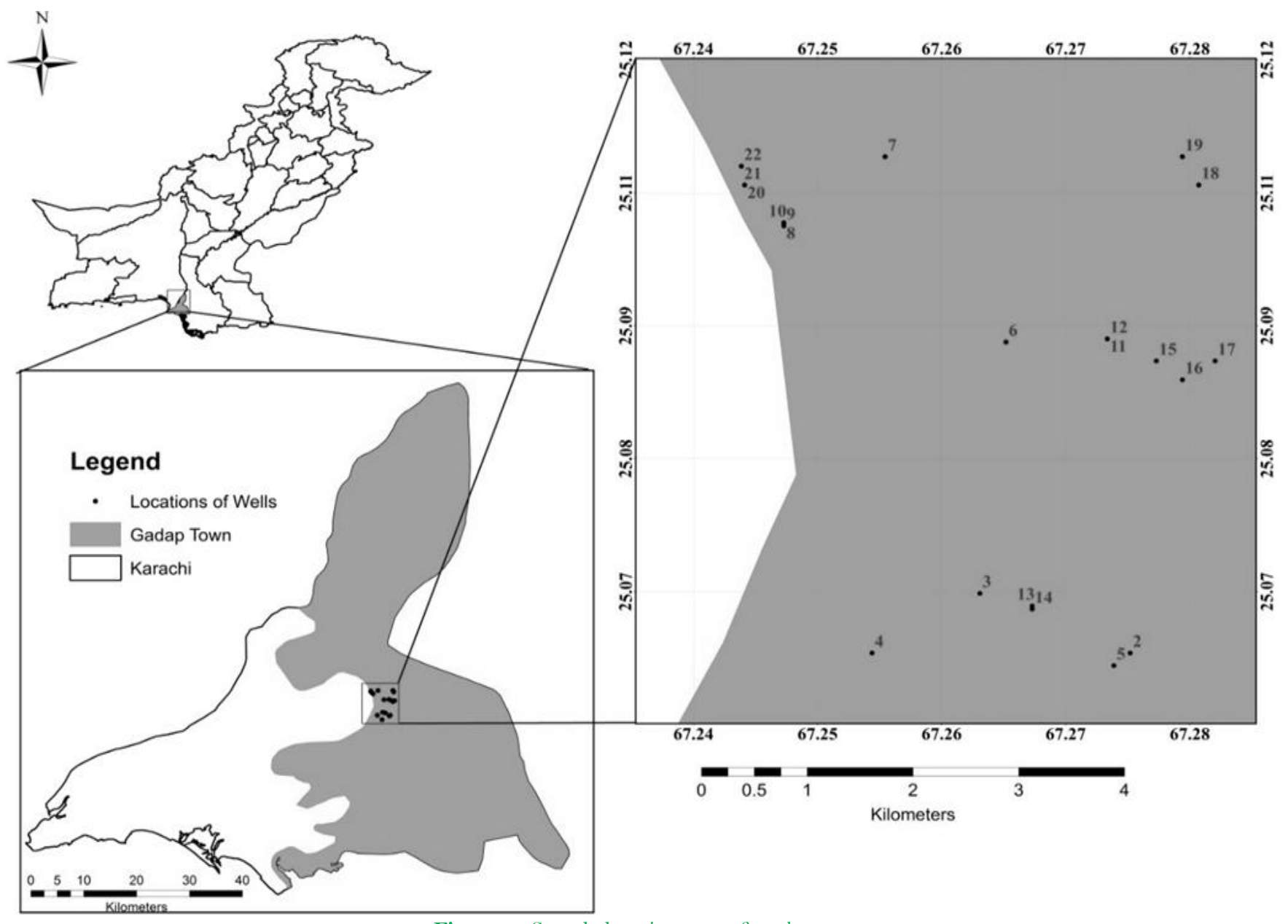

Figure-2. Sample location map of study area.

\subsection{Groundwater Analysis}

All the physico-chemical tests were carried out in the laboratory of Geology Department, University of Karachi. The $\mathrm{pH}$ and TDS/EC of collected groundwater samples $(\mathrm{n}=22)$ were measured with the glass electrode pH meter (ADWA AD 111) and EC meter (ADWA AD 330) respectively. Concentration of sodium and potassium was determined by using flame photometer (Model No. JENWAY PFP7). Sulphate content was tested by gravimetric method, while bicarbonate and chloride were estimated by Argenometric titration method. The method used for the analysis of calcium and total hardness was EDTA Titration Standard Method (1992). Magnesium was estimated as the difference between hardness and calcium with the help of formula. Groundwater samples preserved in the boric acid were analyzed to determine the nitrate concentration by Cadmium Reduction method (HACH-8171) on Spectrophotometer.

\subsection{Water Quality Index (WQI)}

Groundwater quality index of Gadap town was determined by using weighted arithmetic index method as proposed by Brown, et al. [8] to evaluate the water quality status of study area. Physicochemical parameters including $\mathrm{pH}$, TDS, major cations $(\mathrm{Na}, \mathrm{K}, \mathrm{Ca}, \mathrm{Mg})$ and anions $\left(\mathrm{HCO}_{3}, \mathrm{Cl}, \mathrm{SO}_{4}, \mathrm{NO}_{3}\right)$ were used to calculate $\mathrm{WQI}$ of groundwater in Gadap town. WQI is calculated by using following formula.

Where,

$$
\mathrm{WQI}=\sum \mathrm{QnWn} / \sum \mathrm{Wn}
$$

Qn is the quality rating of nth water quality parameter.

Wn is the unit weight of nth water quality parameter.

The quality rating Qn is calculated using the equation .

Where,

$$
\mathrm{Qn}=100^{*}\left[\left(\mathrm{~V}_{\mathrm{n}}-\mathrm{V}_{\mathrm{i}}\right) /\left(\mathrm{V}_{\mathrm{s}}-\mathrm{V}_{\mathrm{i}}\right)\right]
$$

$\mathrm{Vn}$ is the actual amount of nth parameter present.

$\mathrm{Vi}$ is the ideal value of the parameter, $\mathrm{Vi}=0$, except for $\mathrm{pH}(\mathrm{Vi}=7)$.

Vs is the standard permissible value for the nth water quality parameter.

Unit weight $(\mathrm{Wn})$ is calculated using the formula.

$$
\mathrm{W}_{\mathrm{n}}=\mathrm{k} / \mathrm{V}_{\mathrm{n}}
$$

Where, $\mathrm{k}$ is the constant of proportionality and it is calculated using the equation

$$
\mathrm{K}=1 / \sum \mathrm{Vs}=1,2, \ldots, \mathrm{n}
$$




\section{Results and Discussion}

\subsection{Physical Parameters}

The characteristics of collected groundwater samples $(n=22)$ have been summarized in Table 1. Although a few samples are slightly saline and some show yellow color but others are safe in terms of color, taste and odor Table 1. The groundwater $\mathrm{pH}$ is slightly alkaline (mean: 7.5) with subtle variation in range (6.9-8.1) which is within the permissible range of WHO (6.5-8.5) for drinking. The groundwater temperature is low (mean: $28{ }^{\circ} \mathrm{C}$ ) which fluctuates between 25 to $32^{\circ} \mathrm{C}$ suggesting that it's meteoric origin which has been hosted in the aquifers through surface water infiltration [9-17]. Only 5 samples $(10,13,18,21$ and 22) are found turbid Table 1 which are also sewage impacted as indicated by occurrence of pathogenic bacteria Table 1 .

Turbidity in water is function of suspended load including organic particles, bacterio-plankton units, colloids, air bubbles and other non-uniformities in the water samples [18, 19]. In study area, people use to drain sewage into open pits or channels because they live in semi urban set up where lined sanitation is not yet available. As a result, organic matter and solutes are likely to infiltrate through sediments up to aquifers depths, causing high turbidity [20, 21]. Sewage contamination is reported even at the depth of 500 feet in groundwater of study area.

Generally, the sewage contamination occurs at very shallow depth but the presence of sewage at such depths seems to be the function of sediments having good transmissivity and infiltration which is characteristic of alluvial sediments comprising silty-clay to silty-sand. It is consistent with the fact that subsurface rocks in the study area are dominated by silty sand belonging to Nari Formation. These fine clastics have least tendency to hold/adsorb the organic matter on their surface as compared to clays therefore the occurrence of such organic material is plausible in the study area. Total dissolved solids (TDS) and total hardness (TH) of collected samples are found to be highly variable (466-3810 $\mathrm{mg} / \mathrm{L}$ and 250 to $2800 \mathrm{mg} / \mathrm{L}$ respectively) in the groundwater of Gadap town. TDS content occur three times higher than the permissible limit of WHO $(500 \mathrm{mg} / \mathrm{L})$ for drinking water in most of the groundwater samples of study area Table 1. This wide variation in TDS content may attribute to geochemical process and anthropogenic activities [22] in the study area. As discussed earlier, the Gadap basin is an agricultural land where organic matter in the surface soil is ubiquitous. This organic matter is prime driver of generating the organic acids which is significantly leaching the ions from soil and sediments resulting in increased specific conductance or salinity of water [23]. On the other hand, semi-arid climate has also concentrated the salts in the groundwater due to intense evaporation [24, 25]. Likewise, sewage infiltration to the aquifer depth is also augmenting the salt contribution in the groundwater of Gadap basin.

\subsection{Chemical Parameters}

Sodium $(\mathrm{Na})$ and potassium $(\mathrm{K})$ are found to be highly variable in the study area ranging between 52.43-620 $\mathrm{mg} / \mathrm{L}$ and 3.73-105 $\mathrm{mg} / \mathrm{L}$ respectively. Na with a mean of $219.9 \mathrm{mg} / \mathrm{L}$ is found to be the dominant cation among the solutes but only in few samples exceed the permissible limit of WHO $(200 \mathrm{mg} / \mathrm{L})$ set for drinking water Table 2. Likewise, distribution pattern of calcium (Ca) is highly variable (range: $12-520 \mathrm{mg} / \mathrm{L}$ ) in the collected samples Table 3. Similarly, the mean concentration of $\mathrm{Mg}(137.83 \mathrm{mg} / \mathrm{L})$ in the groundwater of Gadap town is double the WHO permissible limit $(50 \mathrm{mg} / \mathrm{L})$ which spans between 12.5 to $388 \mathrm{mg} / \mathrm{L}$ Table 3 . This suggests the role of multiple sources for contributing this element into the aquifer of study area.

On the other hand, $K$ content is marginally high (mean: $15.9 \mathrm{mg} / \mathrm{L})$ in some of the samples $(\mathrm{n}=6)$ violating the desired limit $(12 \mathrm{mg} / \mathrm{L})$ of WHO Table 2. Chloride $(\mathrm{Cl})$ and Bicarbonate $\left(\mathrm{HCO}_{3}\right)$ are dominant anions followed by sulphate $\left(\mathrm{SO}_{4}\right)$ and nitrate $\left(\mathrm{NO}_{3}\right)$. Chloride shows elevated concentration (Mean: $597.31 \mathrm{mg} / \mathrm{L}$ ) in almost all of the collected groundwater samples which is almost double the permissible limit of WHO $(250 \mathrm{mg} / \mathrm{L})$ for dirking water. However, $\mathrm{SO}_{4}$ concentration is found to be within the permissible limit set for drinking water by WHO (250 $\mathrm{mg} / \mathrm{L}$ ) in all of the samples except 5 Table 2.

\subsection{Ionic Interrelationship}

Statistical analysis of the collected groundwater samples shows the strong positive correlation of hardness with all physical and chemical parameters except $\mathrm{HCO}_{3}, \mathrm{NO}_{3}$ and $\mathrm{F}$ and the same pattern is expressed by TDS Table 4. Strong positive correlation of TDS with $\mathrm{Mg}(0.6)$ and $\mathrm{SO}_{4}(0.8)$ indicates the influence of Clay minerals through water rock interaction. Elevated concentration of salts $\left(\mathrm{Na}, \mathrm{K}, \mathrm{Mg}, \mathrm{Cl}, \mathrm{SO}_{4}\right)$ coupled with bacterial occurrence also suggests mixing of sewage with groundwater [26]. On the other hand, very high hardness $(\mathrm{mean}=776.7 \mathrm{mg} / \mathrm{L})$ of these collected samples indicate dissolution of limestone and $\mathrm{Mg}$ release from clays.

\subsection{Hydrofacies Analysis}

Hydrofacies reflect the effect of chemical processes occurring between minerals within the lithological framework and the groundwater [27]. For this purpose, the Piper diagram is used to show the relative concentration of the major cations and anions [27, 28]. The results of groundwater analysis indicate that dominant hydrofacies occurring in the aquifers of Gadap town is $\mathrm{Mg}-\mathrm{Cl}(50 \%)$. 


\begin{tabular}{|c|c|c|c|c|c|c|c|c|c|c|c|c|}
\hline S. No & Locality & Depth (ft.) & Color & Taste & Odor & Turbidity & $\mathrm{pH}$ & TDS mg/L & $\mathrm{EC} \mu \mathrm{s} / \mathrm{cm}$ & Temp. ${ }^{\circ} \mathbf{C}$ & Hardness $\mathrm{mg} / \mathrm{L}$ & Mico. (-ve/+ve) \\
\hline 1 & Chanesar Goth & 360 & Color less & Normal & Odorless & \#NT & 7.3 & 1170 & 150.4 & 28 & 500 & $+\mathrm{ve}$ \\
\hline 2 & Khameso Goth & 350 & Color less & Normal & Odorless & NT & 7.8 & 533 & 682.9 & 26.7 & 250 & $+\mathrm{ve}$ \\
\hline 3 & SorafaqirSorab Goth & 300 & Color less & Normal & Odorless & NT & 7.4 & 920 & 1176 & 31.6 & 270 & $+\mathrm{ve}$ \\
\hline 4 & BadamBagh & 500 & Color less & Normal & Odorless & NT & 7.6 & 1240 & 1562 & 27.1 & 780 & $+\mathrm{ve}$ \\
\hline 5 & Gabol Stop & 400 & Color less & Saline & Odorless & NT & 7.6 & 1050 & 1382 & 28.5 & 560 & $-\mathrm{ve}$ \\
\hline 6 & Manzor Baloch Hotel & 600 & Color less & Saline & Odorless & NT & 7.8 & 836 & 1073 & 25.1 & 450 & TNP \\
\hline 7 & Lucky Farm House & 350 & Color less & Normal & Odorless & NT & 8 & 1370 & 1709 & 28.9 & 700 & TNP \\
\hline 8 & Bhitai Farm House & 330 & Yellow & Saline & Odorless & NT & 7.1 & 2110 & 2707 & 27.9 & 1300 & TNP \\
\hline 9 & Bhitai Farm House & 100 & Color less & Normal & Odorless & NT & 7.3 & 690 & 880.6 & 27.5 & 480 & TNP \\
\hline 10 & Bhitai Farm House & 320 & Color less & Saline & Odorless & Turbid & 7.2 & 1630 & 2093 & 27.9 & 1030 & TNP \\
\hline 11 & Haji KhudaBaksh F.H. & 220 & Color less & Normal & Odorless & NT & 7.4 & 466 & 595 & 26.4 & 350 & TNP \\
\hline 12 & Haji KhudaBaksh F. H. & 400 & Color less & Normal & Odorless & NT & 7.6 & 532 & 681 & 30.2 & 500 & TNP \\
\hline 13 & Dattari Farm House & 500 & Color less & Normal & Odorless & Turbid & 7.6 & 970 & 1240 & 28.3 & 480 & TNP \\
\hline 14 & Sarim Farm House & 340 & Color less & Saline & Odorless & NT & 7.5 & 740 & 947.8 & 28.1 & 450 & TNP \\
\hline 15 & Radho Goth & 400 & Color less & Normal & Odorless & NT & 7.2 & 3390 & 4780 & 29.4 & 2800 & TNP \\
\hline 16 & RadhoJokhio Goth & 220 & Color less & Saline & Odorless & NT & 7.3 & 3810 & 5280 & 28.4 & 2350 & TNP \\
\hline 17 & Goth Rado & 200 & Color less & Normal & Odorless & NT & 7.3 & 771 & 1083 & 30.1 & 700 & TNP \\
\hline 18 & M.Ishaq Baloch Bohlari & 150 & Yellow & Normal & Odorless & Turbid & 7 & 2870 & 4040 & 30 & 2250 & TNP \\
\hline 19 & M.Ishaq Baloch Bohlari & 120 & Color less & Saline & Odorless & NT & 7.3 & 950 & 1484 & 30.1 & 890 & TNP \\
\hline 20 & Gajan Village & 250 & Color less & Normal & Odorless & NT & 8.1 & 790 & 1090 & 28 & *TNP & $+\mathrm{ve}$ \\
\hline 21 & Radho Goth & 170 & Yellow & Saline & Odorless & Turbid & 7.6 & 3210 & 4429 & 29 & TNP & $+\mathrm{ve}$ \\
\hline 22 & Haji Arzi Village & 200 & Color less & Saline & Odorless & Turbid & 8 & 800 & 1104 & 28 & TNP & $+\mathrm{ve}$ \\
\hline
\end{tabular}

Haji Arzi Village

*TNP $=$ Test not performed. 
Table-2. Chemical characteristics of collected groundwater samples.

\begin{tabular}{|c|c|c|c|c|c|c|c|c|c|}
\hline S. No. & $\begin{array}{c}\mathrm{Ca} \\
\mathrm{mg} / \mathrm{L}\end{array}$ & $\begin{array}{c}\mathrm{Mg} \\
\mathrm{mg} / \mathrm{L}\end{array}$ & $\begin{array}{c}\mathrm{Na} \\
\mathrm{mg} / \mathrm{L}\end{array}$ & $\begin{array}{c}\mathrm{K} \\
\mathrm{mg} / \mathrm{L}\end{array}$ & $\begin{array}{c}\mathrm{Cl} \\
\mathrm{mg} / \mathrm{L}\end{array}$ & $\begin{array}{c}\mathrm{HCO} 3 \\
\mathrm{mg} / \mathrm{L}\end{array}$ & $\begin{array}{c}\mathrm{SO4} \\
\mathrm{mg} / \mathrm{L}\end{array}$ & $\begin{array}{l}\mathrm{NO3} \\
\mathrm{mg} / \mathrm{L}\end{array}$ & $\begin{array}{c}\mathrm{Fe} \\
\mathrm{mg} / \mathrm{L}\end{array}$ \\
\hline 1 & 40 & 97.2 & 319.9 & 6.89 & 514 & 1000 & 106 & 1.17 & 0.05 \\
\hline 2 & 120 & 12.15 & 106.8 & 7.1 & 163.12 & 350 & 42 & 0.95 & 0.04 \\
\hline 3 & 12 & 41.31 & 182.4 & 7.69 & 297.86 & 400 & 54 & 0.76 & BDL \\
\hline 4 & 84 & 138.51 & 182.4 & 7.69 & 670.19 & 250 & 84 & 0.81 & 0.02 \\
\hline 5 & 56 & 102.06 & 201.1 & 7.14 & 370.56 & 240 & 112 & 0.82 & BDL \\
\hline 6 & 80 & 60.75 & 163.1 & 8.67 & 372.33 & 250 & 82 & 0.91 & 0.11 \\
\hline 7 & 72 & 126.36 & 244.7 & 8.19 & 659.56 & 340 & 152 & 1.64 & BDL \\
\hline 8 & 168 & 213.84 & 276.6 & 10.32 & 1219.82 & 340 & 260 & 1.45 & 0.34 \\
\hline 9 & 60 & 80.19 & 108.7 & 5.61 & 241.12 & 300 & 77 & 2.71 & BDL \\
\hline 10 & 80 & 201.7 & 197.9 & 9.91 & 886.5 & 310 & 162 & 0.70 & 0.58 \\
\hline 11 & 20 & 72.9 & 52.43 & 3.73 & 156.02 & 230 & 25 & 1.59 & 0.03 \\
\hline 12 & 36 & 99.63 & 70.5 & 4.45 & 187.93 & 260 & 67 & 1.03 & BDL \\
\hline 13 & 24 & 102.06 & 193.6 & 7.38 & 429.06 & 320 & 90 & 0.89 & 0.43 \\
\hline 14 & 40 & 85.05 & 158.1 & 5.53 & 219.85 & 380 & 86 & 0.64 & BDL \\
\hline 15 & 480 & 388 & 386 & 20 & 1524.78 & 340 & 178.86 & 0.04 & 0.024 \\
\hline 16 & 360 & 352.35 & 620 & 25 & 1489.32 & 260 & 341.46 & 0.03 & 0.022 \\
\hline 17 & 172 & 65.61 & 120 & 11 & 141.84 & 300 & 80.13 & 0.03 & 0.01 \\
\hline 18 & 520 & 230.85 & 362 & 19 & 1276.84 & 305 & 211.38 & 0.02 & 0.08 \\
\hline 19 & 180 & 106.92 & 130 & 11 & 177.3 & 330 & 65.04 & 0.02 & 0.07 \\
\hline 20 & 84 & 72 & 165 & 28 & 369 & 850 & 143 & 0.01 & BDL \\
\hline 21 & 378 & 312 & 340 & 105 & 1504 & 490 & 490 & 0.02 & BDL \\
\hline 22 & 116 & 71 & 241 & 32 & 270 & 750 & 132 & 0.01 & $\mathrm{BDL}$ \\
\hline
\end{tabular}

Note: *BDL=Below Deduction Level.

Table-3. The statistical descriptive of the collected samples in the groundwater of the Gadap town.

\begin{tabular}{l|c|c|c|c}
\hline Parameters & Min. & Max. & Mean & SD \\
\hline Depth $(\mathrm{ft})$ & 100 & 600 & 308.2 & 130.4 \\
\hline $\mathrm{pH}$ & 6.95 & 8.1 & 7.47 & 0.31 \\
\hline $\mathrm{TDS}(\mathrm{mg} / \mathrm{L})$ & 466 & 3810 & 1402 & 1008 \\
\hline $\mathrm{EC}(\mu \mathrm{m} / \mathrm{L})$ & 150.4 & 5280 & 1826 & 1466 \\
\hline $\mathrm{Temp}\left({ }^{\circ} \mathrm{C}\right)$ & 31.6 & 31.6 & 28.42 & 1.46 \\
\hline $\mathrm{Ca}(\mathrm{mg} / \mathrm{L})$ & 520 & 520 & 144.63 & 150.48 \\
\hline $\mathrm{Mg}(\mathrm{mg} / \mathrm{L})$ & 388 & 388 & 137.83 & 102.25 \\
\hline $\mathrm{Na}(\mathrm{mg} / \mathrm{L})$ & 52.43 & 620 & 219.19 & 128.08 \\
\hline $\mathrm{K}(\mathrm{mg} / \mathrm{L})$ & 3.73 & 105 & 15.96 & 21.39 \\
\hline $\mathrm{Cl}(\mathrm{mg} / \mathrm{L})$ & 141.84 & 1524.78 & 597.31 & 488.45 \\
\hline $\mathrm{HCO}(\mathrm{mg} / \mathrm{L})$ & 230 & 1000 & 390.6 & 206.1 \\
\hline $\mathrm{SO} 4(\mathrm{mg} / \mathrm{L})$ & 25 & 490 & 138.22 & 108.51 \\
\hline $\mathrm{NO} 3 \quad(\mathrm{mg} / \mathrm{L})$ & 0.67 & 2.71 & 1.15 & 0.55 \\
\hline
\end{tabular}

Table-4. Correlation matrix of the collected samples in the study area.

\begin{tabular}{c|c|c|c|c|c|c|c|c|c|c|c|c}
\hline Parameters & $\mathbf{p H}$ & Hardness & TDS & $\mathbf{C a}$ & $\mathbf{M g}$ & $\mathbf{N a}$ & $\mathbf{K}$ & $\mathbf{C l}$ & $\mathbf{H C O} 3$ & $\mathbf{S O} 4$ & $\mathbf{N O} 3$ & $\mathbf{F e}$ \\
\hline $\mathrm{pH}$ & 1 & & & & & & & & & & \\
\hline Hardness & -0.57 & 1 & & & & & & & & & \\
\hline $\mathrm{TDS}$ & -0.42 & 0.95 & 1 & & & & & & & & \\
\hline $\mathrm{Ca}$ & -0.40 & 0.93 & 0.86 & 1 & & & & & & & & \\
\hline $\mathrm{Mg}$ & -0.45 & 0.95 & 0.96 & 0.81 & 1 & & & & & & \\
\hline $\mathrm{Na}$ & -0.28 & 0.80 & 0.89 & 0.69 & 0.80 & 1 & & & & & \\
\hline $\mathrm{K}$ & 0.16 & 0.92 & 0.53 & 0.50 & 0.48 & 0.39 & 1 & & & & \\
\hline $\mathrm{Cl}$ & -0.40 & 0.91 & 0.96 & 0.80 & 0.94 & 0.84 & 0.52 & 1 & & & \\
\hline $\mathrm{HCO} 3$ & 0.34 & -0.12 & -0.09 & -0.10 & -0.14 & 0.13 & 0.25 & -0.07 & 1 & & & \\
\hline $\mathrm{SO} 4$ & -0.14 & 0.79 & 0.83 & 0.66 & 0.78 & 0.74 & 0.81 & 0.84 & 0.08 & 1 & & \\
\hline NO3 & -0.03 & -0.53 & -0.41 & -0.10 & -0.36 & -0.40 & -0.45 & -0.31 & -0.19 & -0.35 & 1 & \\
\hline Fe & -0.15 & -0.53 & -0.04 & -0.30 & 0.04 & -0.10 & -0.20 & 0.11 & -0.08 & 0.16 & 0.27 & 1 \\
\hline
\end{tabular}

$\mathrm{Na}-\mathrm{Cl}(22.7 \%)$, with lesser abundance $\left(9.10 \%\right.$ each) of $\mathrm{Ca}-\mathrm{HCO}_{3}, \mathrm{Ca}-\mathrm{Cl}$ and $\mathrm{Na}-\mathrm{HCO}_{3}$ Figure 3. The occurrence of $\mathrm{Mg}-\mathrm{Cl}$ facies in the groundwater of study area is due to their high solubility in natural water. The dominance of these two ions clearly indicates the influence of ion exchange and clay mineral alteration or dissolution of dolomite [29-31]. Since the study area is an agricultural land where large amount of clay is present in the soil, the dominance of $\mathrm{Mg}-\mathrm{Cl}$ is legitimate. On the other hand, subsurface rocks are dominated by silty clay with subordinate limestone. These rocks are also assumed to release their sorbed and structural Mg content into the aquifer system within circum-neutral pH conditions. Generally, bicarbonate species dominates in the meteoric groundwater but the occurrence of excessive chloride ion, the bicarbonate is replaced with latter one.

This chloride may originate from various sources including halite and related minerals in evaporate deposits, concentration by evaporation and solution of dry fallout from atmosphere in arid regions. The excessive amount of this ion in the groundwater is due to its conservative nature which makes it free from ion exchange, adsorption and biological activities. On the other hand, anions of strong acids $\left(\mathrm{SO}_{4}+\mathrm{Cl}\right)$ dominate over weak acids $\left(\mathrm{HCO}_{3}+\mathrm{CO}_{3}\right)$ which indicate anthropogenic influence in the groundwater system [32]. It is evident by the fact that intense 
agricultural activity is common in Gadap town since long and the unlined sanitation is also adding up the ions in the groundwater system of study area.

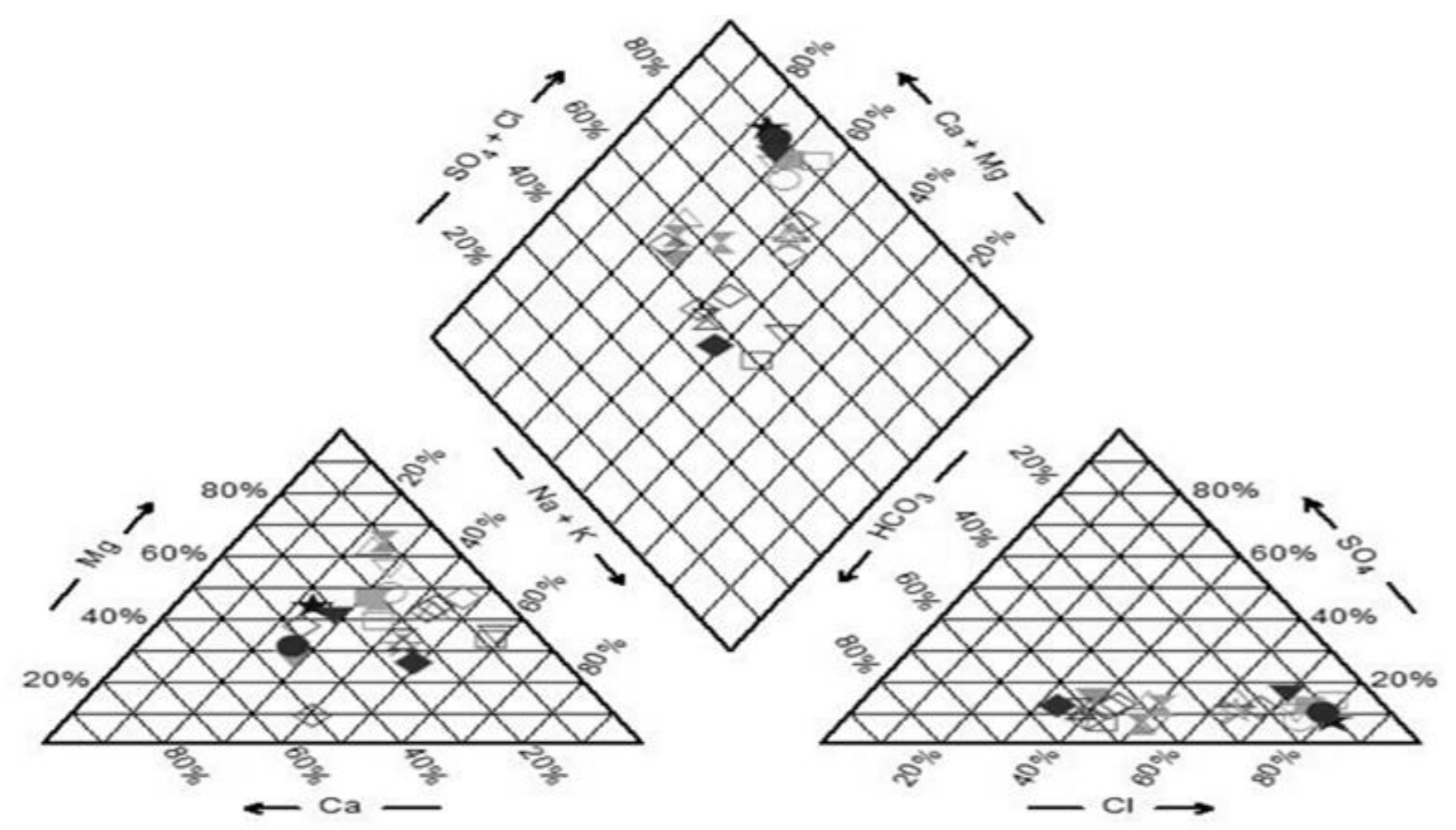

Figure-3. Piper diagram of groundwater samples from GADAP town.

\subsection{WQI for Drinking Water in GADAP}

The WQI considers eleven weighted parameters including $\mathrm{pH}$, TDS, Hardness, $\mathrm{Na}, \mathrm{K}, \mathrm{Ca}, \mathrm{Mg}, \mathrm{HCO}_{3}, \mathrm{Cl}, \mathrm{SO}_{4}$ and $\mathrm{NO}_{3}$ to characterize water quality which has been summarized in Table 6. Weighted arithmetic index method of WQI has been used to assess the quality of groundwater in Gadap town. It is a simple method that aims at giving a single value to water quality by translating the list of parameters and their relative concentrations present in a sample into a single value. This single value in turn provides an extensive interpretation of the quality of water and its suitability for various purposes like drinking, irrigation, industrial etc. [33].

First step for calculating WQI of groundwater is to estimate the quality rating of each parameter using the formula: $\mathrm{Qn}=100^{*}[(\mathrm{Vn}-\mathrm{Vi}) /(\mathrm{Vs}-\mathrm{Vi})]$. If quality rating $\mathrm{Qn}=0$ means complete absence of pollutants, while Qn ranging between $0-100$ indicates that the pollutants are within the prescribed standard and in case of $\mathrm{Qn}>100$ implies that, the pollutants are above the standards [34].

Table-5. Water quality index (WQI) of all collected water samples.

\begin{tabular}{|c|c|c|c|c|c|c|c|c|}
\hline Parameters & Observed value (Vn) & WHO Limits (Vs) & Ideal value (Vi) & Vn-Vi & Vs-Vi & Qn & $\mathrm{Wn}=\mathrm{k} / \mathrm{Vn}$ & Qn*Wn \\
\hline \begin{tabular}{c|}
$\mathrm{pH}$ \\
\end{tabular} & 7.5 & 8.5 & 7 & 0.5 & 1.5 & 33.33 & \begin{tabular}{l|}
0.38 \\
\end{tabular} & 12.88 \\
\hline TDS & 1402.1 & 500 & $\mathrm{O}$ & 1402.1 & 500 & 280.42 & 0.00 & 0.58 \\
\hline Hardness & 927.5 & 500 & $\mathrm{O}$ & 927.5 & 500 & 185.5 & 0.00 & 0.58 \\
\hline $\mathrm{Na}$ & 219.1 & 200 & $\mathrm{O}$ & 219.1 & 200 & 109.55 & 0.01 & 1.45 \\
\hline $\mathrm{K}$ & 15.9 & 12 & $\mathrm{O}$ & 15.9 & 12 & 132.5 & 0.18 & 24.16 \\
\hline $\mathrm{Ca}$ & 144.6 & 75 & $\mathrm{O}$ & 144.6 & 75 & 192.8 & 0.02 & 3.86 \\
\hline $\mathrm{Mg}$ & 137.8 & 150 & $\mathrm{O}$ & 137.8 & 150 & 91.86 & 0.02 & 1.93 \\
\hline $\mathrm{Cl}$ & 597.3 & 250 & $\mathrm{O}$ & 597.3 & 250 & 238.92 & 0.00 & 1.16 \\
\hline $\mathrm{HCO} 3$ & 390.6 & 300 & $\mathrm{O}$ & 390.6 & 300 & 130.2 & 0.00 & 0.96 \\
\hline $\mathrm{SO} 4$ & 138.2 & 250 & $\mathrm{O}$ & 138.2 & 250 & 55.28 & 0.02 & 1.16 \\
\hline \begin{tabular}{l|l}
$\mathrm{NO} 3$ \\
\end{tabular} & 0.7 & 10 & 0 & 0.7 & 10 & 7.0 & 4.14 & 29 \\
\hline \multicolumn{9}{|l|}{$\mathrm{WQI}=16.18$} \\
\hline
\end{tabular}

In collected samples, Qn of TDS (280.42), hardness (185.5), Ca (192.8), Na (109.55), K (132.5), HCO3 (130.2) and $\mathrm{Cl}$ (238.92) are above 100 which indicates that these are the main components responsible for deteriorating the water quality Table 5. Moreover, chloride and bicarbonate of $\mathrm{Ca}, \mathrm{Na}$ and $\mathrm{K}$ are mainly responsible for elevated hardness and very high TDS content in the groundwater of study area. However, the overall result determined by operation on concerned quality parameters the WQI value of 16.18 which according to Brown, et al. [8] is still of pristine in nature Table 6.

Table-6. WQI range, status and possible usage of the water sample (Brown et al. 1972).

\begin{tabular}{l|l|l}
\multicolumn{2}{l}{ Table-6. WQI range, status and possible usage of the water sample (Brown et al. 1972). } \\
\hline WQI & Water quality status (WQS) & Possible usage \\
\hline $0-25$ & Excellent & Drinking, irrigation and industrial \\
\hline $26-50$ & Good & Drinking, irrigation and industrial \\
\hline $51-75$ & Poor & Irrigation and industrial \\
\hline $76-100$ & Very poor & Irrigation \\
\hline Above 100 & Unsuitable for drinking and fish culture & Proper treatment required before use \\
\hline Source: Brown, et al. $[8]$.
\end{tabular}




\section{Conclusion}

Present study revealed that generally the groundwater quality of Gadap town is good for drinking purpose as indicated by water quality index of study area (16.18). However, some parameters are exceeding the permissible limit of WHO in a few wells. Water chemistry is being altered due to the interaction with clays in subsurface environment and anthropogenic activities (agriculture and sewage mixing). More focused study is needed to clearly understand the sources and mechanism responsible for elevating the concentrations of solutes in the groundwater of Gadap Town.

\section{References}

[1] M. Khattak and M. Khattak, "Ground water analysis of Karachi with reference to adverse effect on human health and its comparison with other cities of Pakistan," Journal of Environmental Science and Water Resources, vol. 2, pp. 410-418, 2013.

[2] R. Clarke, Water: The international crisis vol. 30. Earthscan Publications Limited: New York, USA, 1991.

[3] N. Shiddamallayya and M. Pratima, "Impact of domestic sewage on fresh water body," Journal of Environmental Biology, vol. 29, pp. 303-308, 2008.

[4] UN-Water, The United Nations world water development report 3: Water in a changing world. Paris and London: UNESCO and Earthscan, 2009.

[5] B. L. Morris, A. R. L. Lawrence, P. J. C. Chilton, B. Adams, R. C. Calow, and B. A. Klinck, "Groundwater and its susceptibility to degradation: A global assessment of the problem and options for management," Early Warning and Assessment Report Series, RS. 03-3. Kenya, UNEP2003.

[6] M. Chughtai, S. Mustafa, and M. Mumtaz, "Study of physicochemical parameters of rainwater: A case study of Karachi, Pakistan," American Journal of Analytical Chemistry, vol. 5, pp. 235-242, 2014.Available at: https://doi.org/10.4236/ajac.2014.54029.

[7] M. A. Mahboob, I. Atif, and J. Iqbal, "Remote sensing and GIS applications for assessment of urban sprawl in Karachi, Pakistan," Science, Technology and Development, vol. 34, pp. 179-188, 2015.Available at: https://doi.org/10.3923/std.2015.179.188.

[8] R. M. Brown, N. I. McClelland, R. A. Deininger, and R. G. Tozer, "A water quality index: Dowe dare?," Water \& Sewage Works, vol. 117 , pp. 339-343, 1970.

[9] W. D. Collins, "Temperature of water available for individual use in the United States," Water Supply Paper No. 520-F. Washington, DC: USGS, 1925.

[10] C. S. Slichter, "Field measurement of the rate of movement of underground waters," Water Supply and Irrigation Paper, No. 140. Washington DC, USGS, 1905.

[11] M. I. Rorabaugh, "Ground water in Northeastern Louisville, Kentucky with reference to induced infiltration," Water-Supply Paper No. 1360-B. Washington, DC: USGS, 1956.

[12] R. Schneider, "An application of thermometry to the study of groundwater," Water Supply Paper No. 1544-B. Washington, DC: USGS, 1962a

[13] R. Schneider, "Use of thermometry in hydrogeologic studies of glacial deposits at Worthington, Minnesota," Geological Society of America Bulletin, vol. 73, pp. 1305- 1308, 1962b.

[14] R. Schneider, "Distortion of the geothermal field in aquifers by pumping," Professional Paper No. 80O-C. Washington, DC: USGS, 1972 .

[15] J. D. Winslow, "Effect of stream infiltration on ground water temperatures near Schenectady, N.Y," USGS Professional Paper No. 450-C. Washington, DC: USGS, 1962.

[16] Z. E.-S. Salem, M. Taniguchi, and Y. Sakura, "Use of temperature profiles and stable isotopes to trace flow lines: Nagaoka Area, Japan," Groundwater, vol. 42, pp. 83-91, 2004.Available at: https://doi.org/10.1111/j.1745-6584.2004.tb02453.x.

[17] D. Lee, "Method for locating sediment anomalies in lakebeds that can be caused by groundwater flow," Journal of Hydrology, vol. 79, pp. 187-193, 1985.Available at: https://doi.org/10.1016/0022-1694(85)90192-1.

[18] C. J. Gippel, "Potential of turbidity monitoring for measuring the transport of suspended solids in streams," Hydrological Processes, vol. 9, pp. 83-97, 1995.Available at: https://doi.org/10.1002/hyp.3360090108.

[19] WHO, Guidelines for drinking-water quality. Geneva: World Health Organization, 2008.

[20] S. E. Grasby and R. N. Betcher, "Regional hydrogeochemistry of the carbonate rock aquifer, Southern Manitoba," Canadian Journal of Earth Sciences, vol. 39, pp. 1053-1063, 2002.Available at: https://doi.org/10.1139/e02-021.

[21] C. Schmidt, M. Martienssen, and E. Kalbus, "Influence of water flux and redox conditions on chlorobenzene concentrations in a contaminated streambed," Hydrological Processes, vol. 25, pp. 234-245, 2011 .Available at: https://doi.org/10.1002/hyp.7839.

[22] M. Jeevanandam, R. Kannan, S. Srinivasalu, and V. Rammohan, "Hydrogeochemistry and groundwater quality assessment of lower part of the Ponnaiyar River Basin, Cuddalore district, South India," Environmental Monitoring and Assessment, vol. 132, pp. 263-274, 2007.Available at: https://doi.org/10.1007/s10661-006-9532-y.

[23] M. Halim, R. Majumder, S. Nessa, Y. Hiroshiro, K. Sasaki, B. B. Saha, A. Saepuloh, and K. Jinno, "Evaluation of processes controlling the geochemical constituents in deep groundwater in Bangladesh: Spatial variability on arsenic and boron enrichment," Journal of Hazardous Materials, vol. 180, pp. 50-62, 2010.Available at: https://doi.org/10.1016/j.jhazmat.2010.01.008.

[24] A. Farooqi, H. Masuda, and N. Firdous, "Toxic fluoride and arsenic contaminated groundwater in the Lahore and Kasur districts, Punjab, Pakistan and possible contaminant sources," Environmental Pollution, vol. 145, pp. 839-849, 2007.Available at: https://doi.org/10.1016/j.envpol.2006.05.007.

[25] M. H. Panhwar, Groundwater in Hyderabad and Khairpur divisions. Hyderabad Region: Directorate of Agriculture, 1969.

[26] A. A. Cole, T. A. Smecker-Hane, E. Tolstoy, T. L. Bosler, and J. S. Gallagher, "The effects of age on red giant metallicities derived from the near-infrared caII triplet," Monthly Notices of the Royal Astronomical Society, vol. 347, pp. 367-379, 2004.Available at: https://doi.org/10.1111/j.1365-2966.2004.07223.x.

[27] H. Nwankwoala and G. Udom, "Investigation of hydro-geochemical characteristics of groundwater in Port Harcourt City, Nigeria: Implication for use and vulnerability," Journal of Applied Sciences and Environmental Management, vol. 15, pp. 479-488, 2011.

[28] A. M. Piper, "A graphic procedure in the geochemical interpretation of water-analyses," Eos, Transactions American Geophysical Union, vol. 25, pp. 914-928, 1944.Available at: https://doi.org/10.1029/tro25io06p00914.

[29] C. Jeong, "Effect of land use and urbanization on hydrochemistry and contamination of groundwater from Taejon area, Korea," Journal of Hydrology, vol. 253, pp. 194-2 10, 2001.Available at: https://doi.org/10.1016/s0022-1694(01)00481-4.

[30] A. Chkirbene, M. Tsujimura, A. Charef, and T. Tadashi, "Hydro-geochemical evolution of groundwater in an alluvial aquifer: Case of Kurokawa aquifer, Tochigi prefecture, Japan," Desalination, vol. 246, pp. 485-495, 2009.Available at: https://doi.org/10.1016/j.desal.2008.04.057.

[31] J. D. Hem, Study and interpretation of the chemical characteristics of natural water US Geological Survey Water-Supply Paper No. 2254, University of Virginia, Charlottesville, 3rd ed., 1985.

[32] D. Bikundia and D. Mohan, "Major ion chemistry of the ground water at the Khoda Village, Ghaziabad, India," Sustainability of Water Quality and Ecology, vol. 3-4, pp. 133-150, 2014.Available at: https://doi.org/10.1016/j.swaqe.2014.12.001.

[33] T. Abbasi and S. A. Abbasi, Water quality indices vol. 362. Amsterdam, Netherlands: Elsevier, 2012.

[34] V. Gungoa, "Use of water quality indices for water quality assessment in small Island State: A case study in the Northern Aquifer of Mauritius," International Journal of Sciences: Basic and Applied Research, vol. 30, pp. 142-150, 2016. 